\title{
PROFESSIONAL DEVELOPMENT OF SCHOOL PRINCIPALS IN THE PILOT PROGRAM OF 'PEDAGOGICAL FLEXIBILITY': THE ISRAELI CASE
}

\author{
Mali Nets \\ Ministry of Education of Israel, North District, Department of Pedagogical Development, \\ malinets10@gmail.com
}

\begin{abstract}
The past decade constitutes a significant turning point in the orientation of policy makers in the Israeli educational system. This period is characterized by comprehensive structural and pedagogical reforms intended for the promotion of the system's achievements. 'Pedagogical Flexibility', a reform in the professional development of teaching staff implemented in 2015, constitutes a significant breakthrough in the perception of development and learning in Israel. The school principals play a main role in leading the reform and in the development of a new organizational culture in the staff as well. This led to the creation of focused learning frameworks for school principals who sought to improve their knowledge and skill in the leadership of the reform. The article presents the main points of the first pilot program implemented in the North District for the training of 20 school principals in the reform and the main findings from the evaluation of the program, data from a questionnaire, and a focus group. In addition, the article proposes a critical look at the program effectiveness and indicates further focuses for future learning. The article presents a view of the role of the school principal in the leadership of the professional development in Israel and reviews theoretical aspects that arise from the research regarding this issue.
\end{abstract}

Keywords: Professional development of school principals; professional development of teachers; pedagogical leadership

JEL Classification: I280

\section{Introduction and Literature Review}

The immanent connection between students' 'good learning' and the professional competence of teachers is gaining ground in many studies (McKinsey et al. 2007). The psychological and organizational conditions that promote the professional development of teachers strengthen and emphasize the principal's role in the leadership and professional development of the staff (Gold et al. 2003; Leithwood et al. 2006). Distributed leadership (Spillane et al. 2004), collaborative leadership (Southworth, 2011), and leadership focused on teaching and learning (Hattie 2012) were found to promote a reflective discourse of teachers and to empower and promote the teachers' development and efficacy. This leadership is distant from role-based perceptions and adopts distributive approaches. The importance of reflective discourse is attention in a safe environment (Hattie 2012), which - most of the researchers maintain - promotes the teacher's learning. The models of Drago-Severson (2000) indicate that the development and learning of teachers range on an axis of skills and personal development. Good principals must promote these two phases of learning. On the one hand, they must allow the teachers to professionalize in areas of knowledge and to improve skills of teaching and learning in an ongoing and regular manner (Feiman-Nemser 2012). On the other hand, they must promote a language of dialogue and reflectivity on their work and emotions. In addition, the methodology of active learning (Noonan 2014) and the quality of instruction (Poekert 2011) are of decisive importance. Only this constellation may promote teachers and allow schools to lead significant changes in the learners' achievements (Hattie 2012; Stoll et al. 2006). However, a constant improvement in the teacher's capacity and work setting is not a simple task considering the pressures exerted on the school principals by the community (Murphy et al. 2013). Sometimes principals are forced to concentrate their effort on the school 'politics' and are not available to engage in processes of staff development. An in-depth review of the professional literature indicates that it is possible to 
formulate several guiding principles for the optimal development of the staffs.

'Good learning' focuses on 'internal' and 'self' development. The basic assumption is that the development of staff is the creation of internal knowledge, beyond the extension of vocabulary or skills. It is possible that changes will be required in a way in which they know things and not only in the things themselves (Murphy et al. 2013). Moreover, many of the models formulated in the past lack the observation of people to process their experiences (Bredeson 2000; Drago-Severson 2015; Mathibe 2007). They maintain that most of the models appear as if all the teachers are one unit or they are too easily labelled as innovating or opposing the change that the principal wants to lead (Brookfield 2010). A profound change in the learning theories is vital to the increase of the staff's efficacy in every school (Wenger 2006). This assertion reinforces the need to penetrate the barrier 'behind the door of the classroom' and focus the impact on teachers' learning. In doing so, it is important to know that an effective learning of teachers requires an effective learning of principals, so that they can support dialectical learning practices, as Kegan (2000) suggests in the following professional development model.

Table 1. Professional development model (Source: Kegan (2000))

\begin{tabular}{|l|l|}
\hline \multicolumn{1}{|c|}{ The Principal's Role Is to Encourage } & \multicolumn{1}{c|}{ Practice } \\
\hline Development of critical thinking & $\begin{array}{l}\text { The teachers ask themselves meaningful questions that inspire } \\
\text { thinking about perceptions and basic beliefs. }\end{array}$ \\
\hline $\begin{array}{l}\text { Dialogue in a safe and supportive } \\
\text { environment }\end{array}$ & $\begin{array}{l}\text { The teachers share an equal, participative, and collegial } \\
\text { discourse. }\end{array}$ \\
\hline $\begin{array}{l}\text { Challenge to see things from different } \\
\text { perspectives }\end{array}$ & $\begin{array}{l}\text { The teachers dispute the fundamental assumptions, encounter } \\
\text { different opinions, and share different teaching practices. }\end{array}$ \\
\hline Collaborative and experiential learning & $\begin{array}{l}\text { The teachers experience learning through experience and } \\
\text { observation simultaneously of their learning. }\end{array}$ \\
\hline Personal reflection & $\begin{array}{l}\text { Documentation of experience, writing a learning journal, } \\
\text { personal observation of the process and accumulated knowledge }\end{array}$ \\
\hline
\end{tabular}

\section{Main Tenets of the 'Pedagogical Flexibility' Program}

The last decade of the Israeli education system is characterized by far-reaching reforms that gradually expand school autonomy in the management of pedagogy. At the same time, Israel instituted reforms in various arenas of the education system, such as the structure of learning, curricula, budgetary management of schools, and flexible management of the professional development of teaching staff. As a result of these processes, decision makers face new challenges in the training and professional development of school principals. Therefore, the professional development program for school principals in the reform of 'pedagogical flexibility' is the first pilot in Israel that attempts to address the new requirements from school principals. Flexibility, as the reform defines it, is the ability to make decisions and to act independently on pedagogical and organizational issues in professional development. It can be expressed in the planning of needs in the school and teaching staff, in different settings and methods of learning, and in the use of teaching resources and economic resources. The granting of pedagogical and administrative flexibility to the school stems from the basic assumption about the ability of the principal and staff to best identify the professional development needs of the school staff as a whole and of each of the teachers as individuals, in order to facilitate meaningful learning and advancement of students. The training program for school principals in the 'pedagogical flexibility' reform rests on a solid foundation of guiding principles for effective learning; it combines the principle of experiential learning, peer learning, and the implementation of learning, as a basis for strengthening the pedagogic leadership and the professional capacity of the school principal in the program, as shown in the Figure 1. 


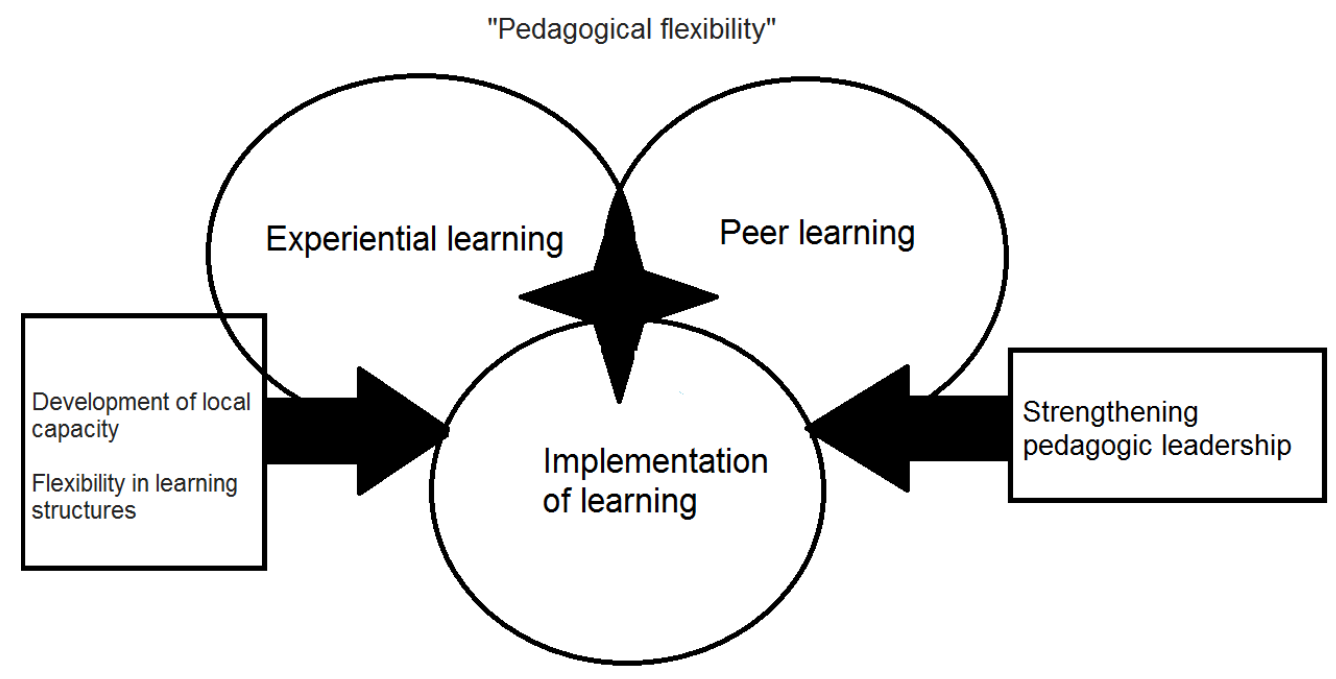

Fig. 1. 'Pedagogical Flexibility' Model

The reform allows full school autonomy in the management of teachers' professional development program. The processes of professional development will be managed inside and outside the school according to the teachers' needs in a variety of frameworks: in professional communities, personal learning, learning in the framework of academic institutions, observation of the lesson, online learning, simulation centre, photographed lessons, and so on. The program encourages the use of diverse methodologies. For example, peer learning, setting questions, conducting observations, holding feedback conversations, professional support groups, analysis of testimonies, reading and discussing the professional literature, learning from successes, action research, and discussion of dilemma, open space, non-formal learning, learning from filmed lessons and analysis of scenarios in learning-teaching processes through simulations.

\section{The Israeli pilot program in the Northern District}

The Ministry of Education based the pilot on clear guiding principles that served as a content and methodological platform for the pilots' training program of 20 school principals in the Northern District. Therefore, it was expected that:

'The school principals in the North District are expected to implement in their school a process of professional development in the 'Pedagogical Flexibility' Model', which includes the characterization of the school needs, the recruitment of the school staff to the process, the identification of difficulties, the choice of areas of learning, the building of a work program, the choice of teaching workers who are expert in their field from the staff for the leadership of the processes of professional development, and pooling of resources...' (Administration of Teaching Workers, 2014 pp.12-13).

The professional development program was formulated as a supportive network for the reforming schools. The selected school principals were in the range of four-five years on the job. The prerequisites for admission to the program included the examination of appropriate pedagogical infrastructures, a dialogic organizational culture, and proven managerial qualities. These parameters were examined in a report submitted by the inspectors in the district from their professional and personal acquaintance with the schools and the principals. 


\section{Methodology}

The course included 40 hours of group learning annually, for five months. The meetings were held once every three weeks. The evaluation sought to achieve two goals: general satisfaction of the school principals from the learning in the program and the degree of application of the learning in the field. Two tools were used in two different stages. A questionnaire that was passed immediately after the learning to all the principals and a focus group that was held with 10 principals from the group, six months after the end of learning.

The group of school principals in the pilot was heterogeneous and was chosen according to the parameters of professional competence for the program. It included principals from different ethnic segmentation, with different seniority in management, from large and small schools and belonging to different age groups. The group included a majority of eleven Jewish school principals and nine from the non-Jewish sector. Among the principals from the non-Jewish sector, one was from the Bedouin sector, five from the Arab sector and three from the Druze sector. On experience in management, there were a majority of eight principals with a seniority of 5-9 years, a minority of three school principals with over 10 years of experience in office and four principals with a short tenure of 3-5 years. The group included a majority of eighteen elementary schools, one junior high school and one high school. The group also included a majority of thirteen large schools with 30-50 staff members, four school principals with 20-30 staff members, a minority of two small schools and one high school with more than 50 staff members (Figure 2).
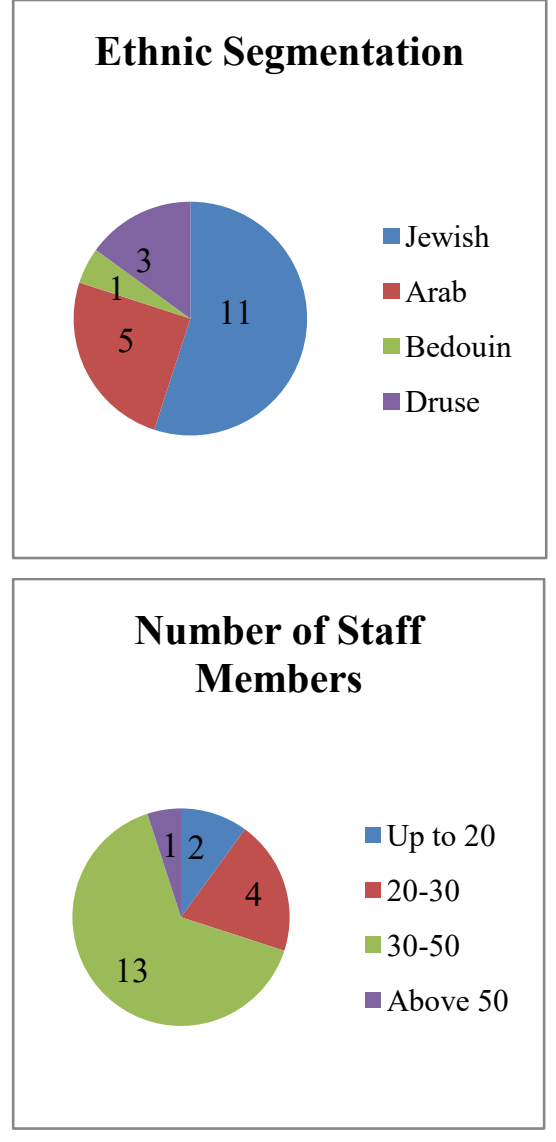
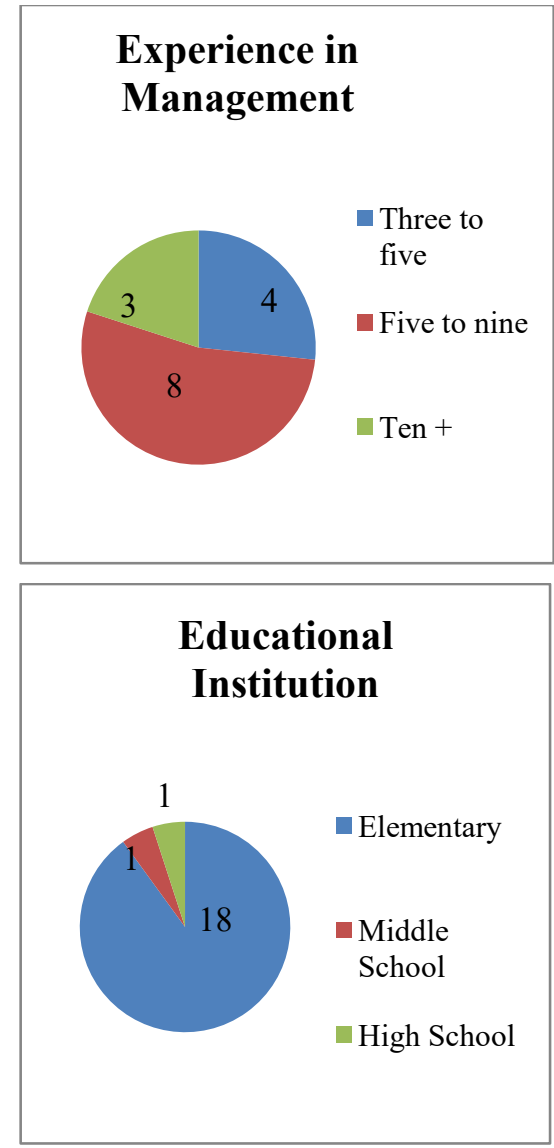

Fig. 2. Characteristics of the assessment group (Source: Author's compilation) 


\section{Results}

\section{Stage 1: The Evaluation Questionnaire}

Part A of the questionnaire included background data. Part B consisted of 24 statements in which the respondents were asked to indicate the degree of their agreement with o the statements on a scale of 1 to 5 (where 1 is 'not at all' and 5 is 'to a large extent'). The questions focused on content, learning processes, guidance and application. Part 3 included two questions that allowed examples of application and place for general comments or suggestions.

Table 2 presents the school principals' general agreement regarding the learning in the course. The statements referred to the planning and actual implementation of learning. It shows that the principals' rating of the compatibility between the methodologies and course content as well as the appropriateness of the course's objectives and their relevance to their work in the field was relatively similar and high (average of 3.80 out of 5).

Table 2. General Agreement regarding the Learning in the Course

\begin{tabular}{|l|c|}
\hline \multicolumn{1}{|c|}{ Statement } & $\begin{array}{c}\text { Mean of Participant Agreement with } \\
\text { the Statement 1-5 }\end{array}$ \\
\hline The course goals are clear to me & 4.0 \\
\hline The goals and the actual implementation corresponded & 3.75 \\
\hline The course contents were relevant to my role & 4.0 \\
\hline $\begin{array}{l}\text { In the learning process, there was a combination between the } \\
\text { theoretical and the practical material }\end{array}$ & 3.58 \\
\hline Mean & 3.83 \\
\hline
\end{tabular}

Table 3 presents general agreement regarding the quality of instruction in the course. These statements were also rated relatively high with an average of more than four out of five. The principals were positive about the facilitator's ability to create a supportive learning environment and to collaborate with the participants. The principals also ranked their ability to share difficulties and dilemmas relatively high.

Table 3. Degree of Satisfaction with the Quality of Instruction in the Course

\begin{tabular}{|l|c|}
\hline \multicolumn{1}{|c|}{ Instruction in the Course } & $\begin{array}{c}\text { Mean of Participant Agreement with } \\
\text { the Statement 1-5 }\end{array}$ \\
\hline The instructor encourages reflective thinking on my work & 4.17 \\
\hline $\begin{array}{l}\text { The instructor encourages the bringing up of difficulties from my } \\
\text { work }\end{array}$ & 4.08 \\
\hline The instructor used the learning time effectively & 4.08 \\
\hline The instructor adjusted the learning methodologies to the content & 4.25 \\
\hline The instructor encourages high order thinking & 4.17 \\
\hline The instructor encourages peer learning & 4.33 \\
\hline Mean & 4.18 \\
\hline
\end{tabular}

Table 4 presents the degree of satisfaction with the process of learning in the course. This set of statements referred to several aspects of learning. The highest rating (over 4 out of 5) was given to the quality of the course's tasks, as well as the statement regarding the reference to the differences 
between the participants. A relatively good score was found (close to 4) in the use of advanced learning technologies. It can be seen that this cluster of statements combines the general aspects of learning and does not hold one organizing axis, as opposed to that presented in the statements in Tables 2 and 3.

Table 4. Degree of Satisfaction with the Process of Learning in the Course

\begin{tabular}{|l|c|}
\hline \multicolumn{1}{|c|}{ Learning Processes in the Course } & $\begin{array}{c}\text { Mean of Participant Agreement with } \\
\text { the Statement 1-5 }\end{array}$ \\
\hline The learning process contributed to my professional development & 4.0 \\
\hline The tasks in the course had applied components & 4.25 \\
\hline There was reference to the participants' differences & 4.08 \\
\hline I felt free to express my opinions & 4.17 \\
\hline Use was made of the participants' field knowledge & 4.17 \\
\hline $\begin{array}{l}\text { Use was made of innovative learning technologies for knowledge } \\
\text { management }\end{array}$ & 3.83 \\
\hline I produced knowledge meaningful to my work & 4.17 \\
\hline Mean & 3.99 \\
\hline
\end{tabular}

Table 5 presents the opinion of school principals relating the Implementation of the Learning in the Field. This cluster of statements shows a high rating (above 4) of the principals for improving their management capabilities in implementing the program. Most of the principals testified that as a result of learning, they improved their management skills. In addition, most of them testified that they promoted work processes following the course. Generally, these statements attest to the high satisfaction of the principals in the contribution of the course to improving their management practices in the reform.

Table 5. Implementation of the Learning in the Field

\begin{tabular}{|l|c|}
\hline \multicolumn{1}{|c|}{ Implementation of the Learning } & $\begin{array}{c}\text { Mean of Participant Agreement with } \\
\text { the Statement 1-5 }\end{array}$ \\
\hline I implemented the learned contents during the learning process & 4.0 \\
\hline I practiced the learned skills during the learning process & 3.92 \\
\hline Following the learning, I improved the quality of my management \\
\hline $\begin{array}{l}\text { Following the learning, I promote processes in my work } \\
\text { environment }\end{array}$
\end{tabular}

Table 6 presents a cluster of open statements in which the principals were asked to present an example of applications in the field and add additional comments. Only one principal responded with an open comment. In addition, only four examples of practical changes in the field were given without extensive detail. 
Table 6. Open Statements

\begin{tabular}{|l|l|}
\hline \multicolumn{1}{|c|}{ Statements: Add a Comment } & \multicolumn{1}{c|}{$\begin{array}{c}\text { Statements: Give Examples of the Implementation of the Learning in } \\
\text { the Field }\end{array}$} \\
\hline $\begin{array}{l}\text { The learning was effective } \\
\text { Only one comment }\end{array}$ & $\begin{array}{l}\text { Setting the schedule for the teachers' professional development } \\
\text { Feeling of a positive approach } \\
\text { Development of initiatives of teachers } \\
\text { Meetings planned ahead of time with staffs }\end{array}$ \\
\hline
\end{tabular}

\section{Stage 2: Focus Group}

A request to participate in the focus group was sent to all the principals who attended the course six months after the end of the learning. The first ten principals who responded were selected to participate in the focus group. There was no deliberate preference for selecting certain managers. The selection was made from the first group that agreed to participate. The principals were asked to address a number of questions presented throughout the meeting with the group and to provide concrete examples to establish the statements. Table 7 shows a representative set of statements given by the principals during the open discussion in the focus group.

Table 7. Select Statements of the Principals in the Focus Group

\begin{tabular}{|c|c|}
\hline Questions for Reference & Select Responses from the Principals' Statements \\
\hline $\begin{array}{l}\text { I form a personal perception } \\
\text { for the professional } \\
\text { development of the teachers in } \\
\text { my school? }\end{array}$ & $\begin{array}{l}\text { 'I understand that flexibility is required ... I listen to the needs of the teachers } \\
\text { and plan accordingly. They choose from the supply of the office. I do not } \\
\text { intervene generally ...' } \\
\text { 'I feel very confused sometimes ... the way is not always clear to me...' }\end{array}$ \\
\hline $\begin{array}{c}\text { I acquire new knowledge on } \\
\text { the professional development } \\
\text { of teachers? }\end{array}$ & $\begin{array}{l}\text { 'I understand more ... I know that they must change but the way is still } \\
\text { long...' } \\
\text { 'I have in the team excellent teachers, they all the time develop and learn. The } \\
\text { knowledge all the time flows to the system.' }\end{array}$ \\
\hline $\begin{array}{c}\text { I know the methodologies of } \\
\text { the professional development } \\
\text { of teachers better? }\end{array}$ & $\begin{array}{l}\text { 'Our pedagogical instructor engages in the planning of the teachers' learning. I } \\
\text { give her absolute autonomy.' } \\
\text { 'I decided that I am not taking upon myself beyond the informing of what } \\
\text { happens ... I rely on my teachers.' }\end{array}$ \\
\hline $\begin{array}{l}\text { I plan a general strategy for the } \\
\text { professional development of } \\
\text { the teachers in my school? }\end{array}$ & $\begin{array}{l}\text { 'This is the hardest part in the system. The flexibility is only an idea in the } \\
\text { office ... we encounter many difficulties.' } \\
\text { 'I sit with the vice [principal]... we build together the program, taking into } \\
\text { account all the constraints in the field...' } \\
\text { 'I allow them almost all that they sought as long as there will be no harm in the } \\
\text { learning of the students...' }\end{array}$ \\
\hline $\begin{array}{l}\text { I implement new models for } \\
\text { the professional development } \\
\text { of the teachers in my school? }\end{array}$ & $\begin{array}{l}\text { 'My teachers learn from one another, they attend the lessons and analyse them } \\
\text {... we did this also before but now they understand what they do ... they know } \\
\text { concepts.' } \\
\text { 'This year we introduced an interesting course for teachers in special education } \\
\text {... I invited the lecturer from the program funds.' }\end{array}$ \\
\hline
\end{tabular}


Study of the representative quotes from the focus group indicates a vague picture of knowledge that the principals acquired in the learning process. The language that the principals chose to use does not include professional terminology (although this appeared in the learning syllabus). Examples of theories of learning anchored in new knowledge were not given. The principals primarily indicate their motivational parts and the feelings that accompany the process of implementation in the field. There is a reference to the 'change of the atmosphere' in the school, but these statements are not anchored in routines and mechanisms that will indicate the establishment of a new learning culture. The principal's leadership in the leadership process is not sufficiently clear. The principals indicated partnership and support but did not present a clear agenda of their action strategy regarding the teachers' professional development. Their role, as arising from the quotes, was to support the system and direct the different factors. There was no use of the words like vision, perception, or cohesive educational agenda. It was expected that the examples that were presented in the open conversations in the focus group would be based on the statements that received high values in the assessment questionnaire. Thus, for example, not one clear answer was given illustrating the statement that received a high percentage of agreement: 'Following the learning, I promote processes in my work environment'. It was barely possible to find innovative learning practices. The reference to 'change' was measured in the diversification of the learning contents but not in the way in which the teachers learn. The principals see the program to be an opportunity for enrichment and diversification, and for the increase of teachers' motivation. It was difficult to identify any expression of recognition in the statements given by the principals with the theoretical perceptions of optimal professional development, concrete strategy of assimilation, or clear conceptualization of the nature of the program and its pedagogical significance in the professional development of teachers and schools as learning organizations.

\section{Conclusions}

The main findings from the evaluation data indicate significant gaps in the effectiveness of the training program. The gap is evident mainly in comparing the data from the evaluation questionnaire that the school principals filled with the data from the focus group. There is a high degree of satisfaction in the data from the evaluation questionnaire, whereas almost no support could be found in the focus group, regarding the questions of implementation of learning in the field, and its impact on the ability of school principals to design innovative and ground-breaking learning among teachers. The principals respond at a high rate to the relevance of the course contents to their work. They also display satisfaction with the processes of learning given in the course and characterize the quality of instruction as high and effective. However, the open statements present eclectic statements that make it difficult to coherently understand the degree of effectiveness on the actual activity of the school principals. The report of improvement and practical change in the field was reduced to reference to vague concepts such as 'teacher motivation' or 'change of atmosphere' and 'a sense of partnership with the teachers'. A possible explanation for this discrepancy is the result of significant limitation and bias in understanding the data from evaluation process that relies entirely on subjective reporting of the participants. The process lacks any factual basis that attests to a significant change in the school culture regarding the professional development of teachers in the reform.

Furthermore, from this review, possible conclusions emerge for three guiding principles in learning. First, learning in an organic environment: effective professional development must occur in the participants' organic environment. Learning in this context creates opportunities for building interschool abilities and for better assimilation of learning (Patton, Parker, \& Tannehill 2015). The training program in the Northern District took place in the traditional framework of courses outside of schools, whereas professional learning in the workplace contributes to personal development (Drago-Severson 2004; Kelley \& Peterson 2012; Lieberman \& Miller 2001).

Second, leading their own learning: through peer training and tasks that require leadership as part of the learning process (Hattie 2012). For this empowerment to occur, it is necessary to have a change in the perceptions and attitudes of the principals regarding the professional development, which is not only imparting knowledge and skills, but also enabling and promoting the thinking about the practice (Hord \& Tobia 2012). The learning is, therefore, a network of knowledge, skills, social relationship, and shared problem solving (Castagnoli \& Cook 2004; Vetter 2012). It is important to allow school 
principals a good opportunity to practice this skill within the training process, within the reform.

Third, engaging in paradigms and personal philosophy: it is important to enable participants to clarify attitudes, perceptions, and beliefs regarding the proposed change. Learning of knowledge and skills does not guarantee a sustainable implementation of high order change (Elmore 2000; Leithwood \& Mascall 2008; Leithwood \& Sun 2012). It is important to keep in mind that the development of people is not a technical act but an experience of cooperation and reciprocal growth (Gold et al. 2003; Lewis \& Murphy 2008; Tannehill 2016). The basic assumption is that development of staff is far more than what is expected or required. This is the creation of internal knowledge, beyond the extension of vocabulary or skills (Gold et al. 2003; (Wenger 2006). It is reasonable to assume that the use of vague and comprehensive terms will be replaced by a more coherent pedagogical agenda, anchored in professional terminology. A more reliable assessment may be obtained as a result of a learning environment that upholds these principles.

As can be seen in this short review, the effective learning challenge has not yet been resolved. The assimilation of learning knowledge and transfer of learning will not be possible as long as there is a gap between learning objectives and the traditional and conservative structures of courses that take place outside the organic work environment. There needs to be a closer alignment between the principal's and the teacher's learning in order to strengthen the principal's role in shaping the environment supporting the professional development of teachers.

\section{References}

Administration of Teaching Workers (2014), Department A for Teaching Workers, Ministry of Education, Jerusalem.

Bredeson, P. V. (2000). The School Principal's Role in Teacher Professional Development. Journal of In-Service Education, 26(2), 385-401.

Brookhart, S. M., \& Moss, C. M. (2015). How to Give Professional Feedback. Educational Leadership, 72(7), 24-30.

Castagnoli, P., \& Cook, N. (2004). Growing Your Own Leaders: The Impact of Professional Development on School Improvement - Summary Report. Nottingham, England: National College for School Leadership.

Drago-Severson, E. (2000). Helping Teachers Learn: A Four-Year Ethnography of One Principal's Efforts to Support Teacher Development. Paper presented at the Annual Meeting of the American Educational Research Association, New Orleans, April.

Drago-Severson, E. (2004) Helping Teachers Learn Principal Leadership for Adult Growth and Development. Corwin Press.

Drago-Severson, E. (2013). Leading Adult Learning: Supporting Adult Development in our Schools. Thousand Oaks, CA: Corwin Press.

Drago-Severson, E. (2015). Reach the Highest Standard in Professional Learning: Learning Designs, A Joint Publication with Learning Forward.

Elmore, R. F. (2000). Building a New Structure for School Leadership. Albert Shanker Institute.

Feiman-Nemser, S. (2012). Teachers as Learners. Cambridge, MA: Harvard Education Press.

Gold, A., Evans, J., Earley, P., Halpin, D., \& Collarbone, P. (2003). Principled Principals? Values-Driven Leadership: Evidence from Ten Case Studies of 'Outstanding' School Leaders. Educational Management \& Administration, 31(2), 127-138.

Hattie, J. (2012). Visible Learning for Teachers: Maximizing Impact on Learning.

Hoerr, T. R. (2008). What Is Instructional Leadership? Educational Leadership 65(4), 84-85.

Hord, S. M., \& Tobia, E. F. (2015). Reclaiming Our Teaching Profession: The Power of Educators Learning in Community. Teachers College Press.

Kegan, R. \& Lahey, L. (2000). Seven Discourses for Development. San Francisco: Jossey-Bass.

Kelley, C, \& Peterson, K.D. (2012). The Work of Principals and Their Preparation: Addressing Critical Needs 
for the Twenty First Century. In M.S Tucker \& J.B Codding (Eds.) The Principals Challenge: Leading and Managing Schools in an Era of Accountability (pp. 247-312). San Francisco: Jossey-Bass.

Leithwood, K., \& Mascall, B. (2008). Collective Leadership Effects on Student Achievement. Educational Administration Quarterly, 44(4), 529-561.

Leithwood, K., \& Sun, J. (2012). The Nature and Effects of Transformational School Leadership: A MetaAnalytic Review of Unpublished Research. Educational Administration Quarterly, 48 (3).

Leithwood, K., Day, C., Sammons, P., Harris, A. \& Hopkins, D (2006). Seven Strong Claims about Successful School Leadership. Nottingham: NCSL.

Lewis, P., \& Murphy, R. (2008). Review of the Landscape: Leadership and Leadership Development. National College for School Leadership, Nottingham, England.

Lieberman, A., \& Miller, L. (Eds.) (2001). Teachers Caught in the Action: Professional Development that Matters. New York: Teachers College Press.

Mathibe, I. (2007). The Professional Development of School Principals. South African Journal of Education, 27(3), 523-540.

McKinsey et al., (2007). Six Themes for Innovation and Improvement. Nottingham: Presentation to NCSL.

Murphy, J., Hallinger, P., \& Heck, R. H. (2013). 'Leading via Teacher Evaluation: The Case of the Missing Clothes?'. Educational Researcher, 42(6), 349-354.

Noonan, J. (2014). In Here, Out There: Professional Learning and the Process of School Improvement, Harvard Educational Review, 84(2), 145-161.

Patton, K., Parker, M., \& Tannehill, D. (2015). Helping Teachers Help Themselves: Professional Development that Makes a Difference. NASSP Bulletin, 99(1), 26-42.

Poekert, P. (2011). The Pedagogy of Facilitation: Teacher Inquiry as Professional Development in a Florida Elementary School. Professional Development in Education, 37(1), 19-38.

Southworth, G. (2011). Leading Learning and Teaching in Primary Schools. Nottingham, England: National College for School Leadership

Spillane, J. (2004). Distributed Leadership: What's All the Hoopla. Evanston, IL: Northwestern University, Institute for Policy Research

Stoll, L., Bolam, R., McMahon, A., Wallace, M., \& Thomas, S. (2006). Professional Learning Communities: A Review of the Literature. Journal of Educational Change, 7(4), 221-258.

Tannehill, D. (2016). My Journey to Become a Teacher Educator. Physical Education and Sport Pedagogy, 21(1), 105-120.

Vetter, A. (2012). Teachers as Architects of Transformation: The Change Process of an Elementary-School Teacher in a Practitioner Research Group. Teacher Education Quarterly, 39(1), 27-49.

Wenger, E. (2006) Communities of Practice: A Brief Introduction. Retrieved from: http://www.ewenger.com/theory/index.htm 